\title{
Peningkatan Kualitas dan Kapasitas Produk Olahan Berbasis Perikanan Laut dengan Teknologi Tepat Guna
}

\author{
Mutiara Nugraheni $^{*}$, Titin Hera Widi Handayani ${ }^{1}$, Agung Utama ${ }^{2}$, Arif Marwanto ${ }^{3}$ \\ 1,2,3 Universitas Negeri Yogyakarta \\ 11Program Studi Pendidikn Teknik Boga, Fakultas Teknik, Universitas Negeri Yogyakarta \\ 2Program Studi Manajemen, Fakultas Ekonomi, Universitas Negeri Yogyakarta \\ 3Program Studi Pendidikan Teknik Mesin, Universitas Negeri Yogyakartar \\ *e-mail: mutiara nugraheni@uny.ac.id, titin hwh@uny.ac.id, Agung utama@uny.ac.id, \\ arifmarwanto@uny.ac.id
}

\begin{abstract}
This community service aims to solve the problems faced by the Mina Bahari 45 group related to the quality and production capacity to support product marketing. The activities done were to carry out the appropriate technology transfer activities and the strengthening of marketing that is strengthening the quality and capacity of processed products based on sea fisheries, strengthening production management; renovation and re-lay out the product display. The results of community service related to strengthening production management are the selection and handling of raw materials, processing and packaging. Operationalization of automatic cracker frying Machine and industrial scale steamer as well as renovation and re-lay out display place to support off-line marketing in Depok Beach. The use of appropriate technology can increase production capacity at least by 15\% and improve the quality of products produced that include texture, shape and color and the availability of a product display space that is safe for products, attractive and adequate.
\end{abstract}

Keywords: quality, capacity, fishing, technology

\begin{abstract}
Abstrak
Pengabdian masyarakat ini bertujuan untuk memecahkan permasalahan yang dihadapi oleh Kelompok Usaha Bersama Mina Bahari 45 terkait kualitas dan kapasitas produksi untuk mendukung pemasaran produk. Hal yang dilakukan adalah melakukan kegiatan transfer teknologi tepat guna dan penguatan pemasaran yaitu penguatan kualitas dan kapasitas produk olahan berbasis perikanan laut, penguatan manajemen produksi; renovasi, re-lay out tempat display produk. Hasil pengabdian pada masyarakat terkait dengan penguatan manajemen produksi adalah sharing pemilihan dan penanganan bahan baku, proses pengolahan dan pengemasan. Operasionalisasi mesin penggorengan kerupuk otomatis dan steamer skala industri serta renovasi dan re-lay out tempat display untuk mendukung pemasaran offline di Pantai Depok. Penggunaan teknologi tepat guna dapat meningkatkan kapasitas produksi minimal sebesar 15\% dan memperbaiki kualitas produk yang dihasilkan yang meliputi tekstur, bentuk dan warna serta tersedianya ruang display produk yang aman bagi produk, menarik, dan memadai.
\end{abstract}

Kata kunci: kualitas, kapasitas, perikanan, teknologi

\section{PENDAHULUAN}

Kawasan wisata Pantai Depok terletak di Kabupaten Bantul, Daerah istimewa Yogyakarta. Mata pencaharian penduduk di sekitarnya adalah membuka warung makan seafood dan olahan berbasis perikanan laut, meskipun secara kualitas dan kuantitas belum sepenuhnya sesuai dengan standar dan kebutuhan wisatawan/konsumen yang mengunjungi Pantai Depok. Pengembangan kapasitas dan kualitas produksi beberapa produk terkendala dengan terbatasnya kapasitas peralatan yang dimiliki oleh KUB Mina Bahari 45.

Kelompok yang berperan dalam pengembangan, pengolahan dan pemasaran produk berbasis perikanan laut di Pantai Depok adalah Kelompok Usaha Bersama Mina Bahari 45. KUB Mina Bahari 45 beranggotakan kelompok pengolah dan pemasar olahan perikanan laut, dan memiliki anggota sebanyak 25 orang dan semuanya adalah wanita.

Potensi yang dimiliki oleh KUB Mina Bahari 45 yang ada di Pantai Depok adalah ketersediaan hasil tangkapan ikan laut 2-3 ton/ hari. Ikan yang ditangkap bervariasi dari segi 
nilai ekonominya. Ikan merupakan bahan hewani yang mudah mengalami kemunduran mutu dan bahkan mudah rusak jika tidak segera ditangani dengan tepat dan cepat (Nugraheni, 2013). Potensi ini cukup besar untuk dikembangkan menjadi produk yang memiliki umur simpan yang lama, sehingga dapat digunakan sebagai oleh-oleh wisatwan di Pantai Depok. Beberapa permasalahan di bidang produksi adalah penggunaan fasilitas penggorengan dan proses pengadukan masih manual sehingga kapasitas kerupuk ikan yang dihasilkan masih kecil. Fasilitas steamer masih skala rumah tangga untuk memproduksi tahu bakso ikan. keterbatasan peralatan produksi ini menyebabkan proses produksi lambat sehingga produk yang dihasilkan masih sedikit dan belum memenuhi kebutuahn wisatawan/konsumen. Permasalahan lain adalah belum adanya kemasan yang sesuai aturan label pangan dan tidak adanya fasilitas display produk yang aman, menarik dan memadai.

Upaya pengembangan produk berbasis perikanan dilakukan oleh tim pengabdi bersama dengan KUB Mina Bahari 45 dan Dinas Pertanian Pangan Kelautan dan Perikanan Kabupaten Bantul, khususnya bidang Kelautan dan Perikanan Daerah Istimewa Yogyakarta. Harapannya adalah dihasilkannya produk olahan berbasis perikanan laut yang dapat menjadi produk unggulan wisata pantai di Kabupaten Bantul. Indentifikasi dan upaya untuk mengangkat suatu produk diarahkan untuk menjadi produk unggulan daerah, sehingga diharapkan dapat meningkatkan kunjungan wisatawan, menjadi icon suatu tempat dan meningkatkan perekonomian masyarakat setempat.

Kerjasama ini sejalan dengan Rencana Pembangunan Jangka Menengah daerah (RPJMD) Dinas Pertanian Pangan Kelautan dan Perikanan Kabupaten Bantul yaitu meningkatkan kesejahteraan masyarakat perikanan, dengan cara meningkatkan kualitas dan produktivitas pelaku usaha pengolahan hasil perikanan. Sehingga terdapat penumbuhan pelaku usaha di bidang pengolahan dan pemasaran produk hasil perikanan, peningkatan kapasitas SDM pelaku usaha (Anonim, RPJMD 2016-2021). Program PPPUD ini diharapkan dapat bersinergi dengan KUB Mina Bahari 45, Dinas Pertanian, Kelautan Bantul, dan Universitas Negeri Yogyakarta dalam mengembangkan produk unggulan di Pantai Depok.

\section{METODE}

Metode yang dilakukan untuk menyelesaikan masalah yang dihadapi oleh KUB Mina Bahari 45 adalah dengan melakukan diskusi antara tim pengabdi dari UNY, KUB Mina Bahari 45, dan Kepala Bidang Kelautan Kabupaten Bantul sehingga menghasilkan solusi terbaik yang dapat mendukung KUB Mina Bahari 45 dalam memproduksi, memasarkan olahan berbasis perikanan laut yang dapat menjadi unggulan wisata Pantai di Kabupaten Bantul.

Metode yang digunakan untuk menyelesaikan permasalahan kualitas produk adalah dengan melakukan pelatihan dan pendampingan untuk meningkatkan kualitas produk kerupuk ikan dan tahu bakso, serta produk berbasis perkanan yang lain. Hal ini dilakukan dengan ceramah dan diskusi terkait pengadaan, pemilihan dan penanganan bahan, proses produksi yang aman, baik dan benar, pengoperasian alat dengan tepat, praktik pengolahan produk dan kemasan yang tepat.

Metode yang digunakan untuk menyelesaikan kapasitas produksi adalah dengan introduksi peralatan teknologi tepat guna penggorengan otomatis dan pengadaan steamer rak skala industri. Renovasi tempat display dan perbaikan display dilakukan untuk mendukung pemasaran di Pantai. Hal yang dilakukan terkait renovasi tempat display adalah perubahan layout dan penambahan fasilitas display dan penyimpanan produk.

Evaluasi kualitas produk dilakukan secara organoleptik (warna, aroma, tekstur, rasa). Evaluasi kapasitas dilakukan dengan membandingkan dengan penggunaan peralatan yang dimiliki saat ini. Evaluasi juga dilakukan untuk mengetahui pelaksanaan pendampingan dan pengoperasian peralatan. 


\section{HASIL DAN PEMBAHASAN}

Pelaksanaan pengabdian pada masyarakat telah dilaksanakan yaitu memberikan materi terkait dengan pengadaan, pemilihan dan penanganan bahan, proses produksi yang aman, baik dan benar, pengoperasian alat dengan tepat, kemasan dan kondisi penyimpanan. Materi yang diberikan adalah karakteristik ikan yang baik, bagaimana penanganan bahan baku yang tepat, personal higiene, kebersihan lingkungan, manajemen produksi dan kemasan. Pelaksanaan pengabdian pada masyarakat ini juga melakukan introduksi teknologi tepat guna dalam hal ini adalah penggorengan kerupuk otomatis dan steamer tray untuk meningkatkan kualitas dan kuantitas produk yang dihasilkan. Penggunaan teknologi tepat guna ini diharapkan dapat meningkatkan produktivitas, dan kualitas produk. Hal ini sejalan dengan Pratama et.al (2020) yang membuktikan bahwa penggunaan teknologi pada pembuatan gula semut yaitu menggunakan mesin oven pengering gula semut dan mesin sealer nitrogen dapat meningkatkan produktivitas pengusaha.
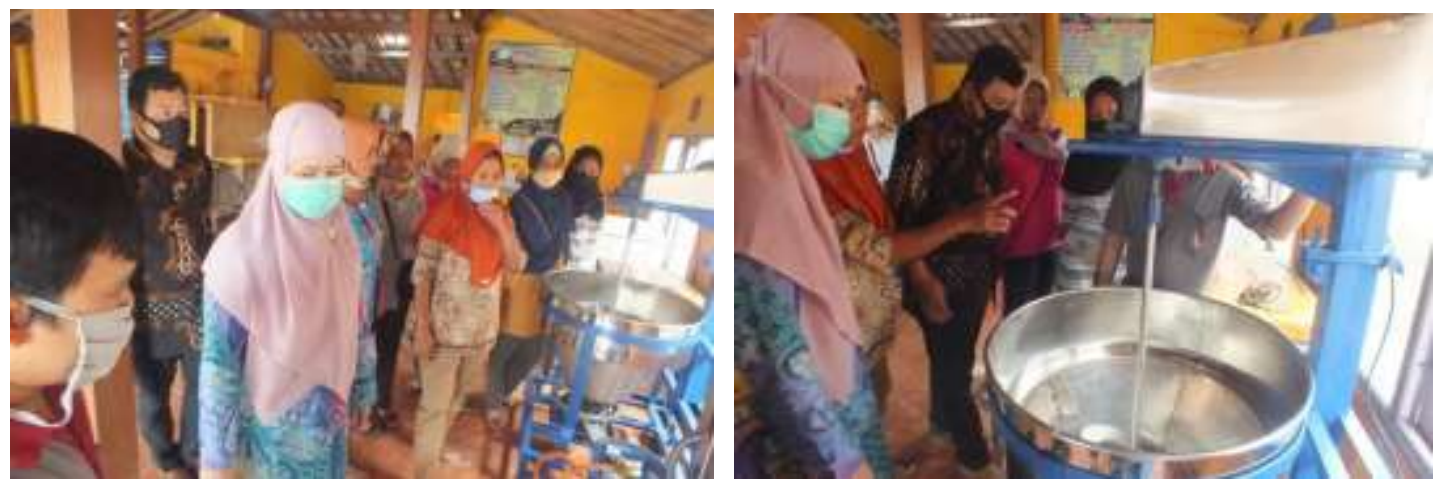

Gambar 1. Penjelasan terkait cara penggunaan peralatan penggorengan otomatis dan steamer rak skala industri.

Pertemuan selanjutnya adalah praktik pengolahan kerupuk ikan dan tahu bakso serta pengoperasian peralatan penggorengan otomatis untuk produk kerupuk ikan, dan steamer rak skala industri untuk tahu bakso (Gambar 1 dan 2). Ikan yang memiliki nilai ekonomis yang tidak tinggi diolah untuk pembuatan kerupuk ikan dan tahu bakso yang memiliki nilai jual dan umur simpan yang lebih lama (Nugraheni et al., 2016). Pengendalian pada pembuatan kerupuk ikan adalah pemilihan ikan yang digunakan, ikan yang digunakan bisa beberapa jenis, namun berupa ikan daging putih, sehingga tekstur dan pengembangannya bisa baik. Kondisi ikan baik dan belum mengalami penurunan mutu (misalkan: tekstur lembek, aroma menyimpang). Jika kondisi fisik ikan sudah kurang baik, maka kerupuk tidak bisa mengembang sehingga ukurannya kecil dan teksturnya keras. Ikan berkualitas baik yang dapat digunakan memiliki ciri-ciri mata jernih, insang berwarna merah, tekstur kembali ke posisi semula jika tidak ditekan, aroma tidak menyimpang (Nugraheni, 2013).

Ikan merupakan bahan yang digunakan pada pembuatan kerupuk ikan, hal untuk meningkatkan nilai gizi dan cita rasa ikan. Salah satu bahan baku yang digunakan pada pembuatan kerupuk ikan ini adalah bahan yang memiliki kandungan karbohidrat tinggi yaitu pati, yang memiliki peranan utama dalam proses pemekaran produk (Despita et al., 2015). Kualitas kerupuk yang dihasilkan, diantaranya adalah volume pengembangan, kerenyahan dan tingkat kesukaan oleh konsumen dipengaruhi oleh mutu tepung yang digunakan. Perbandingan tepung, ikan, udang akan mempengaruhi mutu kerupuk yang dihasilkan. Daya kembang kerupuk akan semakin berkurang bila presentase kandungan tepung lebih banyak dibanding dengan bahan pengisi (udang, ikan, dll). Jumlah telur yang digunakan dalam pembuatan kerupuk ini berfungsi sebagai emulsifier dan mengikat komponen adonan. Telur digunakan juga sebagai pengembang alami dalam pengolahan kerupuk. Adonan kerupuk harus diuleni sampai kalis agar mendapatkan kerupuk yang mengembang sempurna. 
Berdasarkan evaluasi kualitas kerupuk ikan dibandingkan kerupuk ikan yang dihasilkan sebelum pendampingan adalah persentase kerupuk yang dapat mengembang sempurna. Sebelum pendampingan, 30\% kerupuk tidak dapat mengembang sempurna, namun setelah pendmapingan dan menggunakan penggorengan otomatis $100 \%$ adonan kerupuk dapat mengembang sempurna. Dampak dari pengembangan tersebut adalah meningkatnya kerenyahan kerupuk yang dihasilkan, sebab kerenyahan kerupuk dipengaruhi oleh besarnya pengembangan kerupuk pada waktu digoreng. Hal ini dijelaskan bahwa pada saat digoreng, maka pada kerupuk akan membentuk rongga-rongga didalamnya. Makin banyak rongga-rongga yang terbentuk akan semakin renggang strukturnya, sehingga mudah dipatahkan, sehingga makin tinggi daya kembangnya, maka akan semakin tinggi kerenyahan yang dihasilkan.

Berdasarkan evaluasi kualitas kerupuk dari warna, maka warna kerupuk ikan yang dihasilkan lebih terang, karena ikan yang digunakan adalah tipe ikan berdaging putih (baracuda, tengiri dan sebagainya). Ikan yang memiliki daging kemerahan akan menghasilkan warna lebih kecoklatan pada kerupuk setelah digoreng (Wiranti, 2015). Hal ini disebabkan oleh warna mioglobin dalam otot (daging ikan), yang jika melalui proses pemanasan (penggorengan) akan menghasilkan warna coklat, sedangkan ikan dnegan daging putih memiliki kandungan mioglobin rendah mengakibatkan warna kerupuk lebih terang.

Aroma yang dihasilkan dari pembuatan kerupuk ikan adalah aroma ikan, disebabkan oleh kandungan protein yang terurai menjadi asam amino khususnya asam glutamat yang akan menimbulkan rasa dan aroma yang lezat (Suwarsito, 2007). Rasa gurih yang dihasilan pada keriupuk ikan disebabkan oleh asam amino pembentuk cita rasa yang ada dalam ikan yaitu glisin, alanin, lisisn serta asam glutamat (laiya et.al,m 2014).

Beberapa hal yang harus dikendalikan pada saat pengolahan kerupuk ikan adalah ikan yang digunakan harus benar-benar segar, jika ikan sudah menurun kualitasnya, maka kerupuk tidak bisa mengembang dengan baik, minyak yang digunakan cukup banyak, sehingga dapat menjadi penghantar panas yang baik (kerupuk mengembang), penggorengan dimulai dari minyak dingin, jika minyak panas, maka kerupuk tidak mengembang dengan baik.
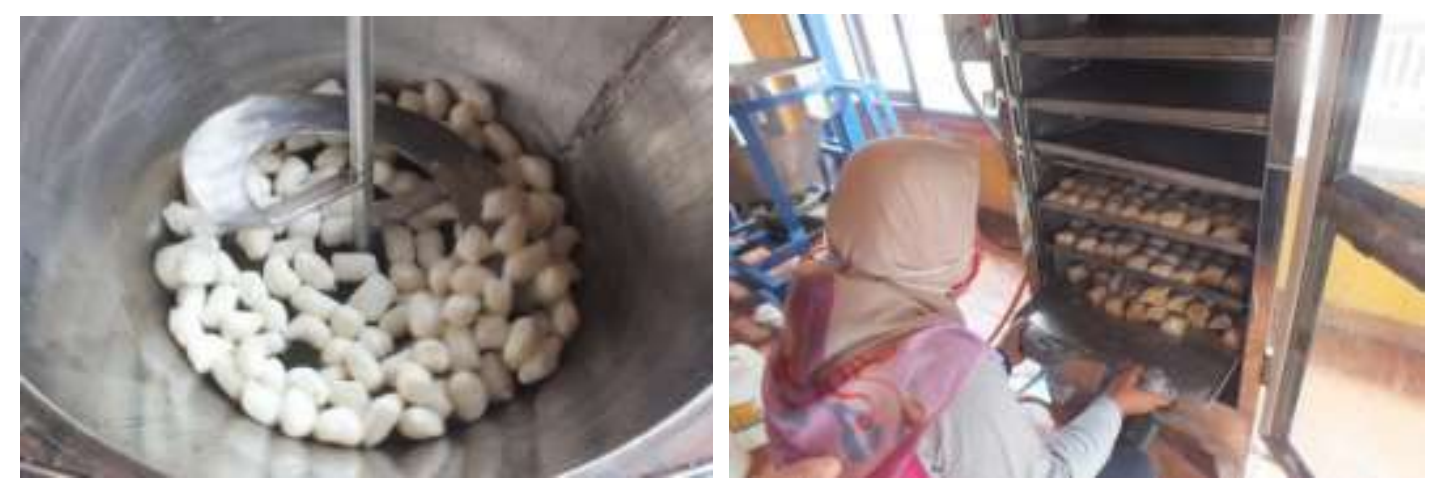

Gambar 2. Penggunaan alat penggoreng otomatis dan steamer rak skala industri untuk kerupuk ikan dan tahu bakso

Proses penggorengan harus menjadi perhatian terkait dengan perbandingan volume minyak yang digunakan dengan jumlah kerupuk mentah yang digoreng. Jika terlalu banyak kerupuk mentahnya, maka pengembangan menjadi tidak sempurna, dan hal ini berdampak pada tingkat kerenyahan kerupuk yang dihasilkan. Proses pengemasan kerupuk harus menunggu kerupuk benar-benar dingin, sehingga tidak menyebabkan kerupuk melempem karena masih adanya uap air yang keluar. 

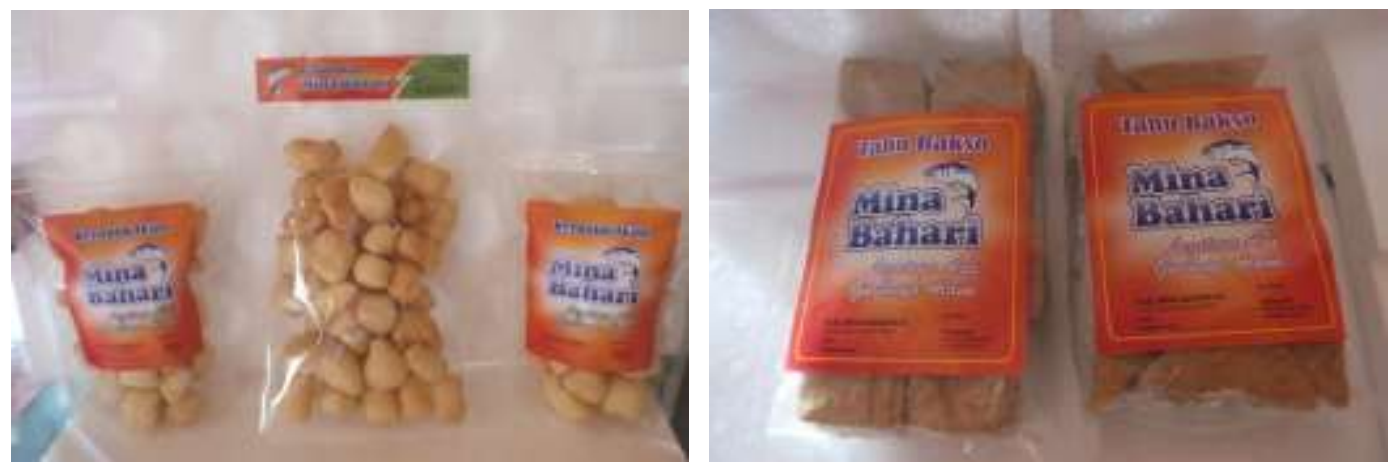

Gambar 3. Kerupuk Ikan dan tahu bakso yang dihasilkan menggunakan penggorengan otomatis dan steamer rak skala industri

Berdasarkan evaluasi organoleptik terhadap kerupuk ikan baik aroma, rasa, tekstur diperoleh informasi bahwa rasa disukai (rasa ikan terasa), aroma disukai (terasa aroma ikan), tekstur di sukai kenyal tapi tidak liat, Warna disukai (kuning keemasan dan terang). Berdasarkan dengan hal ini, maka respon konsumen terhadap pengembangan kedua produk ini yaitu tahu bakso baik (Gambar 3).

Pendampingan pembuatan tahu bakso dilakukan baik secara teoritus maupun praktik. Berdasarkan evaluasi yang dilakukan perlu adanya freezer sebagai penyimpan tahu bakso sebelum dipasarkan,, sehingga memberikan keamanan bagi konsumen. Penyimpanan dengan freezer diharapkan dapat melindungi produk dari berbagai kontaminasi baik kontaminasi fisik, kimiawi maupun mikrobiologis.

Pengendalian pada pembuatan tahu bakso adalah perbandingan antara ikan dan beberapa jenis tepung yang digunakan. Ikan yang digunakan harus ikan yang memiliki ciri-ciri ikan segar, belum mengalami penurunan mutu. Jenis tepung yang digunakan adalah tepung tapioka dan tepung terigu. Proses pembuatan tahu bakso dilakukan dengan menggunakan beberapa bahan yaitu daging ikan, tepung tapioka, dan tahu magel. Pada pembuatan adonan tahu bakso, maka digunakan bahan pengisi. Bahan pengisi yang dimaksud adalah bahan bukan daging. Fungsinya adalah memperbaiki sifat emulsi, mereduksi penyusutan selama pemasakan, memperbaiki sifat fisik dan cita rasa, menurunkan biaya produksi, meningkatkan flavor, meningkatkan daya ikat air, meningkatkan karakteristik fisik, kimiawi dan sensori produk.

Penggunaan bahan pengisi dalam adonan bakso maksimum 50\% dari berat daging. Namun hal ini tergantung dengan harga jual yang akan ditetapkan dan target konsumennya. Pada umumnya, bahan pengisi yang dipakai adalah bahan-bahan yang mengandung pati. Tepung yang biasa digunakan dalam pembuatan donan bakso adalah tepung tapioka, tepung sagu atau tepung aren yang dapat digunakan secara terpisah maupun campuran dengan jumlah $10-100 \%$ atau lebih dari berat daging. Pada pembuatan tahu bakso di KUB Mina Bahari 45 digunakan perbandingan tepung tapioka, dan ikan: 1:1. Sehingga diperoleh adonan tahu bakso yang kenyal, namun tidak liat. Penambahan pati optimum untuk mendapatkan gel strength maksimum, sangat tergantung pada tipe pati yang ditambahkan. Pati yang dapat digunakan sebagai bahan pengisi untuk memperkuat adalah pati kentang, tapioka dan maizena. (Rahussidi et al., 2016). Pemilihan ikan akan berdampak pada warna adonan tahu bakso ikan yang dihasilkan, ikan yang memiliki daging putih akan memberikan warna adonan tahu bakso putih, sedangkan jika ikan yang digunakan adalah ikan berdaging merah, maka warna adonan tahu bakso ikan cenderung coklat/gelap. Kombinasi daging dan tepung dengan kombinasi yang tepat dapat menghasilkan adonan yang kenyal (Hertanto et al., 2018).

Kondisi tahu yang digunakan adalah tahu magel yaitu tahu yang mengalami proses penggorengan stengah matang, sehingga masih ada juicy nya. Keseragaman ukuran tahu yang digunakan juga menjadi faktor yang harus diperhatikan. Ukuran yang tidak seragam dapat berdampak pada penampilan dan jumlah tahu bakso yang dihasilkan. Penampilan yang 
memadai harus didukung dengan jumlah isian adonan tahu bakso. Keseragaman ukuran tahu yang digunakan dapat digunakan untuk memprediksi jumlah adonan yang dibutuhkan.

Berdasarkan evaluasi organoleptik terhadap tahu bakso baik aroma, rasa, tekstur diperoleh informasi bahwa rasa disukai, aroma terasa aroma ikan, disukai, tekstur di sukai kenyal tapi tidak liat. Berdasarkan dengan hal ini, maka respon konsumen terhadap pengembangan kedua produk ini yaitu tahu bakso baik.

Berdasarkan evaluasi dari tim pengabdi, ketua KUB dan anggota KUB Mina Bahari 45, produk yang dihasilkan pada saat pendampingan dan menggunakan alat penggorengan otomatis lebih baik daripada yang menggunakan penggorengan manual. Perbaikan yang nampak adalah tingkat pengembangan yang merata, tekstur renyah dan warna merata, dan kapasitas produk persatuan waktu lebih lebih besar. Demikian pula tahu bakso yang dihasilkan memiliki tekstur yang kenyal dan kapasitas produksinya per satuan waktu lebih besar. Pada saat pendampingan juga diserahkan secara resmi tiga alat yang untuk mendukung kegiatan KUB Mina Bahari 45 yaitu alat penggoreng otomatis, steamer rak skala industri dan freezer (Gambar 4).
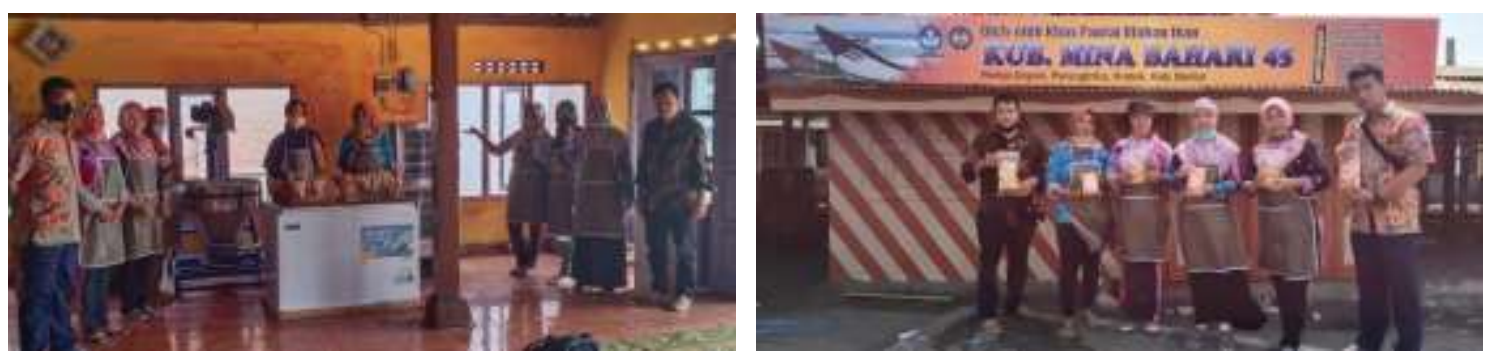

Gambar 4. Penyerahan peralatan dan pembuatan dua produk yang menjadi produk unggulan KUB Mina Bahari 45

Renovasi fasilitas display, re-lay out display dan pengemasan produk dilakukan untuk memperbaiki penampilan fisik bangunan, keamanan produk, penampilan penyajian produk. Renovasi fasilitas displai (showroom) dilakukan dengan perbaikan ruang dan pintu shoowroom. Kondisi showroom berada di pinggir pantai, sehingga bagian-bagian showroom lama berupa besi (pintu dan engsel) rusak parah. Perbaikan dan penggantian dilakukan untuk memperindah penampilan (Gambar 5). Perbaikan keamanan produk dengan mengadakan freezer untuk penyimpanan produk basah yang tergolong froozen food (tahu bakso serta produk yang lain). Penyimpnan produk yang termasuk frozen food berada pada suhu $-16^{\circ} \mathrm{C}$, hal ini karena menekan pertumbuhan bakteri dan proses enzimatis, tetapi tidak mengakibatkan kerusakan sel (Sari dan Hadiyanto, 2013).
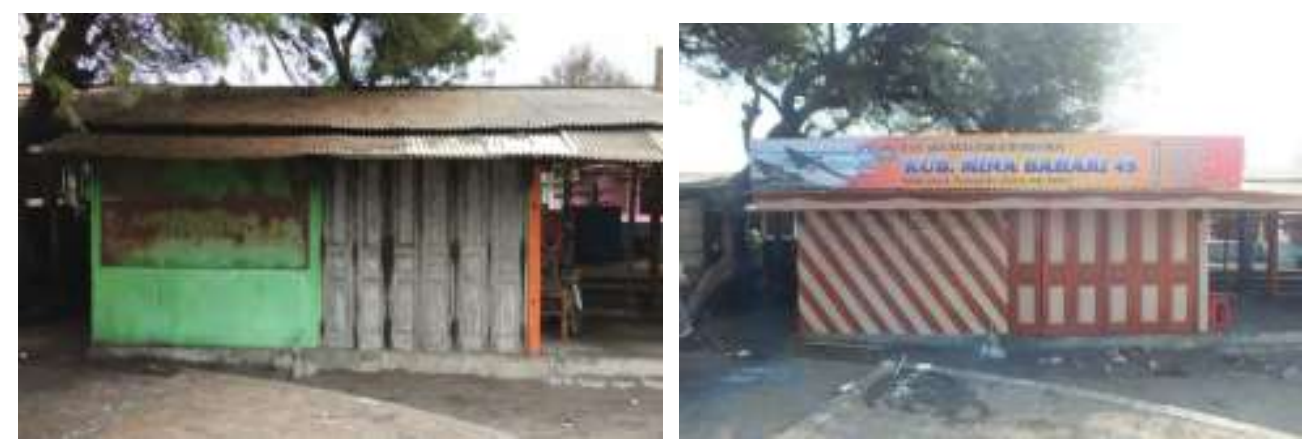

Gambar 5. Penampakan showroom KUB Mina Bahari 45 sebelum dan sesudah direnovasi

Berdasarkan evaluasi yang diberikan ke peserta menunjukkan bahwa dengan pelatihan yang diberikan, maka peserta dapat memahami cara pemilihan bahan baku, cara penanganan 
yang tepat, cara pengolahan yang baik, cara pengemasan yang sesuai sehingga berdampak pada peningkatan motivasi untuk semakin mengembangkan kapasitas produksi produk berbasis ikan.

Beberapa perubahan yang ada setelah dilakukan tahun pertama PPPUD adalah kapasitas produksi meningkat, keseragaman pengembangan kerupuk ikan, tekstur tahu bakso kenyal tapi tidak liat, kemasan sesuai produk yang dihasilkan, dan renovasi tempat display produk milik KUB Mina Bahari 45.

Tabel 1. Perubahan kapasitas produksi, karakteristik produk, dan jangkauan pemasaran setelah kegiatan PKM

\begin{tabular}{|c|c|c|c|}
\hline No & Variabel & Sebelum PKM & Setelah PKM \\
\hline 1. & Kapasitas produksi kerupuk ikan/hari & 600 gram ikan & 2 kg ikan \\
\hline 2. & Kapasitas produksi tahu bakso/hari & 200 buah & 1000 buah \\
\hline 3. & $\begin{array}{l}\text { Keseragaman pengembangan kerupuk } \\
\text { ikan }\end{array}$ & $\begin{array}{l}30 \% \text { tidak } \\
\text { mengembang } \\
\text { sempurna }\end{array}$ & $\begin{array}{l}100 \% \text { mengembang } \\
\text { sempurna }\end{array}$ \\
\hline 4. & Kerenyahan & Belum merata & $\begin{array}{l}\text { Merata di seluruh } \\
\text { bagian kerupuk }\end{array}$ \\
\hline 5. & Kekenyalan tahu & kenyal & $\begin{array}{l}\text { Kenyal namun tidak } \\
\text { liat }\end{array}$ \\
\hline 6. & Label kemasan & Belum ada label & $\begin{array}{l}\text { Ada label } \\
\text { informatif }\end{array}$ \\
\hline
\end{tabular}

\section{KESIMPULAN}

Pelaksanaan PPPUD sesuai dengan rencana yang dirancang antara Tim PPPUD UNY bersama dengan KUB Mina Bahari 45 dan Dinas Pertanian dan Kelautan Kabupaten Bantul. Pelatihan yang dilaksanakan meliputi penjelasan terkait dengan pemilihan bahan baku, penanganan bahan, proses pengolahan, pengemasan dan pemasaran. Penggunaan mesin penggoreng otomatis dan steamer rak skala industri mendorong perubahan kapasitas produksi, karakteristik produk dan jangkauan pemasaran setelah dilaksanakan PPPUD. Peningkatan kapasitas produksi minimal sebesar $15 \%$ baik untuk produk kerupuk ikan maupun tahu bakso. Evaluasi ketrampilan bagi anggota KUB Mina menunjukkan telah memahami penggunaan peralatan penggorengan otomatis dan steamer rak, serta memahami tiap proses yang dapat menyebabkan penurunan kualitas produk.

\section{UCAPAN TERIMA KASIH}

Tim PPPUD UNY mengucapkan terima kasih kepada Direktorat Riset dan Pengabdian Masyarakat, Deputi Bidang Penguatan Riset dan Pengembangan, Kementrian Riset dan Teknologi/Badan Riset dan Inovasi Nasional, dengan Nomor Kontrak 058/SP2H/LT/DRPM/2020.

\section{DAFTAR PUSTAKA}

Anonim, 2016-2021. Rencana Pembangunan Jangka Menengah Daerah Kabupaten Bantul. Despita, R., Yuliasih, S. Rahmi, A. (2015). Pengaruh penambahan tepung tapioka terhadap warna, kerenyahan, dan rasa kerupuk ampas susu kedelai. Prosiding Seminar Hasil Penelitian Tanaman Aneka Kacang dan Umbi, 340-345. 
Hertanto, M. Y., Larasati, A., Issutarti. (2018). Pengaruh penambahan tepung terigu terhadap mutu bakso jamur tiram putih. Teknologi dan Kejuruan, 41(2), 164-172.

Laiya N, Rita MH, Nikmawatisusanti Y. 2014. Formulasi Kerupuk Ikan Gabus Yang Disubtitusi Dengan Tepung Sagu. Jurnal ilmiah perikanan dan kelautan. 2 (2): 81-87.

Nugraheni, M. (2013). Pengetahuan Bahan Pangan Hewani. Graha Ilmu

Nugraheni, M., Handayani, T. H. W., Utama, A. (2016) Teknologi Presto pada produk berbasis ikan air tawar kaya kalsium. Inoteks, 20(2), 171-187.

Pratama, A. K. Y., Wisdaningrum, O., Nugrahani, M. P. ( 2020). Pendampingan dan penerapan teknologi untuk peningkatan produkstivitas usaha mikro gula semut. Dinamisia, 4(2), 275284.

Rahussidi, M. A., Sumadianto, Wijayanti, I. (2016). Pengaruh perbandingan konsentrasi tepung tapioka (Manihott uttilissima) dan tepung kentang (Solanum tuberosum) terhadap kualitas bakso ikan lele (Clarias batrachus). Jurnal Pengolahan \& Bioteknologi Hasil Perikanan, 5(3), 17-24.

Sari, D. A., Hadiyanto. (2013). Review: Teknologi dan metode penyimpanan makanan sebagai upaya memperpanjang shelf life. Jurnal Aplikasi Teknologi Pangan, 2(2): 52-59.

Suwarsito. 2007. Pengaruh L-Karnitin Terhadap Kadar Lemak Daging Dan Komposisi Tubuh Ikan Patin (Pengasius hypopthalmus). Jurnal Perikanan. 9 (1) : 63-68.

Wiranti T. (2015). Pengaruh Proporsi Tapioka, Tepung Garut, dan Daging Ikan Patin Terhadap Sifat Organoleptik Kerupuk. Ejurnal Boga. 4 (1) : 28-36. 